\title{
THE MODERN INTERFAITH RELATIONS IN EGYPT
}

\author{
Oksana V. Nizamutdinova \\ Kazan Federal University, Kazan, Russian Federation
}

\begin{abstract}
Introduction. This paper deals with the dynamics of changes in relations between followers of Christianity and Islam in Egypt since the 1970s. The relevance of our research consists in the fact that the aforementioned world religions play a significant role in the formation of Egyptians' mindset and the predestination of their behavior. The novelty of the topic is associated with the attempt to speak about the problem of interfaith relations in the light of main "players' view". The list of players includes the State, the Coptic Orthodox Church, the Muslim Brotherhood Movement and other Islamic institutions under presidential control. The research is aimed at analyzing the interfaith relations in Egypt over the last fifty years in order to determine their current status. To achieve this goal, we consistently solved a number of tasks. At first, we found out prerequisites of problem's emergence, then we described interests of each group, considered their activity and made general implications. Methods. For complex study of the role of the State and religious structures, we have applied an institutional research method. A historical and a system method allowed us to comprehend a genesis of the question and show how internal and external factors affect these institutions. Results. We've made the conclusion that the main impact on interfaith relations was made by authoritarian leader who specified their evolution in a favorable way for him. The official Islamic clerics get benefits from the President and therefore do not criticize his power. The Coptic Orthodox Church also collaborates with the State under the threat of terroristic attacks. The Muslim Brotherhood Movement shows independent views, so it can condemn or support President's decisions based on their vision of the role of religion in the country. Thus, in the $21^{\text {st }}$ century, the choice between Secularization and Islamization will became principal for Egypt's development.
\end{abstract}

Key words: interfaith dialogue, religious policy, the Coptic Orthodox Church, al-Azhar University, the Muslim Brotherhood Movement, Islam, Christianity.

Citation. Nizamutdinova O.V. The Modern Interfaith Relations in Egypt. Vestnik Volgogradskogo gosudarstvennogo universiteta. Seriya 4, Istoriya. Regionovedenie. Mezhdunarodnye otnosheniya [Science Journal of Volgograd State University. History. Area Studies. International Relations], 2018, vol. 23, no. 6, pp. 164-172. (in Russian). DOI: https://doi.org/10.15688/jvolsu4.2018.6.13

УДК 323

ББК $66.3(4 / 8)$
Дата поступления статьи: 14.12.2017 Дата принятия статьи: 20.03.2018

\section{СОВРЕМЕННЫЕ МЕЖРЕЛИГИОЗНЫЕ ОТНОШЕНИЯ В ЕГИПТЕ}

\author{
Оксана Викторовна Низамутдинова \\ Казанский федеральный университет, г. Казань, Российская Федерация
}


лексного изучения роли государства и религиозных структур мы использовали институциональный метод исследования. Исторический и системный методы позволили проанализировать генезис вопроса и описать влияние внутренних и внешних факторов на институты. В результате проделанной работы удалось прийти к выводам, что на современные межрелигиозные отношения в Египте решающее влияние оказывает авторитарный лидер, который определяет их развитие в выгодном ему направлении. Исламское «официальное» духовенство получает заработную плату из государственного бюджета, поэтому не критикует президента и тем легитимирует его власть. Коптская православная церковь, опасаясь террористических атак, также ищет защиты под его крылом. Ассоциация «Братья-мусульмане» отличается независимостью суждений, порицая или поддерживая решения президента исходя из собственных представлений о роли религии в стране. В XXI в. выбор между секуляризацией или исламизацией общества станет определяющим для развития Египта.

Ключевые слова: межрелигиозный диалог, религиозная политика, Коптская православная церковь, Университет ал-'Азхар, ассоциация «Братья-мусульмане», ислам, христианство.

Цитирование. Низамутдинова О. В. Современные межрелигиозные отношения в Египте // Вестник Волгоградского государственного университета. Серия 4, История. Регионоведение. Международные отношения. -2018. - Т. 23, № 6. - C. 164-172. -DOI: https://doi.org/10.15688/jvolsu4.2018.6.13

Введение. Проблема терпимости и диалога между религиями сопровождает человека с момента зарождения у него представлений о едином Боге. Монотеист, в отличие от политеиста, противопоставляет не «своих» и «чужих» богов, а свою веру в единого Бога и прочие, по его мнению, заблуждения. Непримиримость позиций на территориях сожительства приверженцев разных верований обусловливает высокий уровень конфронтации между ними. Не стал исключением из этого правила и Египет, земля которого, наравне с Палестиной, равным образом почитается в иудаизме, христианстве и исламе.

В Новейшее время Египет пережил волну национально-освободительного движения и последующее обретение независимости в 1952 году. Однако суверенитет не обеспечил стране высокий экономический рост и процветание. Разочарование в социалистическом строе, сотрудничавшем с атеистами, и поражение в Шестидневной войне с Израилем 1967 г. стали главными причинами зарождения в 1970-х гг. радикального исламизма. В это время в стране появилось бесчисленное множество партий и движений, которые разрешали себе использовать насильственные методы борьбы. Противоборствующие стороны отказывались от решения споров в законном порядке, предпочитая этому оказание силового давления на друг на друга.

В Египте действует несколько главных сил, в сферу интересов которых входит религиозная политика. Во-первых, это само государство, во-вторых, это связанные с ним институты официального ислама: Университет
ал-'Азхар, Дар ал-'Ифта' (Муфтият), Министерство вакфов, Высший совет по делам ислама и контролируемые ими мечети. В-третьих, значительное влияние на религиозную жизнь египтян оказывает ассоциация «Братьямусульмане» (далее - АБМ). В-четвертых, со стороны христиан выступает самая авторитетная и древняя церковь Египта - Коптская православная церковь (далее - КПЦ). Деструктивное влияние на межрелигиозный диалог оказывает деятельность террористических группировок, акции которых направлены в равной степени против «неверного» государства, «заблудших» мусульман и христиан. Вне анализа остаются Коптская католическая церковь, евангелические церкви и $c y$ фийские братства.

Методы. В целях объективности мы стремились воздержаться от принятия точки зрения какой-либо из сторон конфликта. Для комплексного изучения роли государства и религиозных структур был использован институциональный метод исследования. Исторический и системный методы позволили проанализировать генезис вопроса и описать влияние внутренних и внешних факторов на институты.

Анализ. В семидесятые годы ХХ в. Египтом руководил 'Анвар Садат (1971-1981). Стремясь обрести поддержку исламской общественности, президент сделал ряд шагов, которые обострили отношения между коптами и мусульманами и вылились в открытые столкновения. Причина произошедшего кроется в том, что глава государства проигнорировал назревшую проблему реформирования закона, регулирующего вопросы постройки и 
ремонта христианских культовых сооружений. Действующий с 1856 г. Указ о веротерпимости Хатт-и Химайуни позволял властям бесконечно затягивать выдачу разрешений на строительство церквей. Заявка на постройку должна была удовлетворить 10 условиям, после чего, подписанная губернатором, передавалась президенту. Кроме того, на 1980 г. пришелся всплеск апокалиптических настроений среди коптов после одобрения 'Анваром Садатом поправки ко второй статье Конституции, характеризующей шари'ат как главный источник права.

Для выхода из сложившейся ситуации президент стал прибегать к ряду мер, в число которых входили переговоры со сторонами, осуждение виновных (по его мнению) людей и групп на государственных заседаниях и в выступлениях перед СМИ, а также прямое административное давление (заключение под арест, лишение свободы).

В силу своей непопулярности после подписания Кемп-Девидских соглашений с Израилем 'Анвар Садат не смог успокоить общество. В 1981 г. он был убит в результате покушения боевика из организации «Священный джихад» Халада 'Ахмада ал-'Исламбули. Следующий президент страны Хосни Мубарак (1981-2011), предвидя разрастание проблемы, вынудил уйти в подполье радикальные группы и, судя по всему, заключил с коптским патриархом соглашение о сотрудничестве, которого стороны строго придерживались вплоть до 2011 года.

При новом лидере межрелигиозный конфликт не прекратился. Необходимо отметить, что большинство поводов для конфликта имеет бытовую природу, когда уличные перепалки, связь с незамужней девушкой или удержание от принятия ислама перерастают в погромы и массовые драки.

Сотрудник Центра Карнеги на Ближнем Востоке копт Гиргис Фахми приводит два подобных примера [1, p. 192]. В 2005 г. в деревне Кафр Салама (провинция ал-Шаркийа) после устной перепалки христианин убил мусульманина, в результате чего мусульмане атаковали собственность христиан этой деревни. В целях примирения сторон глава полиции встретился с ними и без суда вменил всем христианам заплатить общую сумму в раз- мере 500 тыс. египетских фунтов семье потерпевшего. Убийца и его семья должны были покинуть деревню. Некоторые христиане отказались платить за преступление, которое они не совершали, пока не получат компенсацию за свое имущество. За «отказ соблюдать условия перемирия» они подверглись аресту.

В июне 2008 г. в деревне Назла (провинция ал-Файум) мусульмане атаковали дома христиан после слухов, что женщина, принявшая ислам несколькими годами ранее и вышедшая замуж за мусульманина, ушла от него. Сначала христиане не хотели принимать участие в диалоге, но полиция угрозами заставила их это сделать.

Как мы видим, при попытках урегулирования конфликта игнорируется судебное разбирательство. Возможно, это связано с тем, что сама правовая система Египта содержит в себе противоречия. Например, в Конституции Египта с 1980 г. говорится о шари 'ате как об основном источнике права, хотя в то же время Конституция гарантирует равенство всех граждан независимо от их религиозной принадлежности. Это взаимоисключающие понятия, ведь шари'ат как минимум делит людей на мусульман и зимми и предписывает последним дополнительные правила поведения. В связи с этим приходим к выводу, что идея правового государства трудно согласовывается с классической теорией власти в исламе ${ }^{1}$.

Схожего мнения придерживаются консервативные исламисты, среди которых видное место занимает шейх 'Абу 'Исма'ил, активно продвигающий идею исламизаиии Египта в парламенте с 1976 по 1990 год. Шейх противопоставляет демократию и принцип исламской шуры - совета, который не вмешивается в «божественный порядок» [8, p. 31-32].

Вышеперечисленные факты указывают на то, что при поиске выхода из кризиса власть не инициировала общественную дискуссию. Принятое решение озвучивалось и приводилось в исполнение административным давлением или шантажом. Когда силовые структуры хотели повлиять на несговорчивую сторону, то они приглашали религиозного авторитета, которого не всегда можно назвать независимой третьей стороной. Коптская интеллигенция критиковала такие встречи, так как на 
них не соблюдались равные права сторон. После революции 2011 г. премьер-министр 'Исам Шараф ${ }^{2}$ учредил Национальный комитет правосудия (далее - НКП) для разбора подобных ситуаций. В сентябре 2011 г. после очередного инцидента в деревне ал-Маринаб (Асуан) НКП выработал рекомендации для государства, к которым эксперты пришли после анализа причин столкновения. Этот труд был оставлен властями без внимания, что дало повод обществу подозревать правящую Национально-демократическую партию в использовании межрелигиозного конфликта как повода, отвлекающего внимание граждан от фальсификации прошедших в 2010 г. парламентских выборов.

НКП полностью повторил судьбу комиссии ал-'Утайфи, созданной в 1972 г. для расследования массовых беспорядков в деревне ал-Ханка.

Шейх Университета ал-'Азхар Ахмад алТайаб (2010 - н. в.), будучи главным лицом официального ислама, продолжил традицию протокольных встреч с высшими чинами КПЦ, как это сложилось со времен его предшественника Мухаммада ал-Тантави (1996-2010). После теракта в церкви двух Святых (Александрия) 1 января 2011 г. он посетил коптского патриарха Шенуду III (1971-2012), чтобы выразить соболезнования в связи с трагедией. Шейх озвучил идею создания в Египте организации «Дом египетской семьи» (далее - ДЕС) для предотвращения подобных ситуаций в будущем ${ }^{3}$. Инициатива нашла поддержку в верхах (или была оттуда подсказала) и вскоре получила законодательное оформление через решение премьерминистра № 1279 от 12 октября 2011 года.

ДЕС объединил под своим крылом не только ал-'Азхар и КПЦ, но и Евангельскую апостольскую церковь, Коптскую католическую церковь, Англиканскую церковь и экспертов в области социологии, истории и религиозных наук.

Управление ДЕС состоит из тандема шейха ал-'Азхара и патриарха КПЦ, которые осуществляют общее руководство. Ниже стоит Собрание секретарей (доверенных лиц) в составе от 11 до 27 человек. Из них клирикимусульмане назначаются шейхом, а священники - патриархом. Данному учреждению поручено организовывать плановые и внеплано- вые собрания, наблюдать за исполнением решений ДЕС. Организация имеет свое Исполнительное собрание, которое возглавляет главный секретарь и вице-секретарь. Рядовыми членами подразделения считаются докладчики комитетов ДЕС и докладчики со стороны. ДЕС включает 7 комитетов:

1) комитет религиозного призыва;

2) комитет образования;

3) комитет по делам молодежи;

4) комитет по делам семьи;

5) комитет по работе при чрезвычайных ситуациях;

6) комитет по работе со СМИ;

7) связующий комитет.

Своими целями ДЕС считает сохранение национального единства страны, поддержание контактов с государственными структурами, формирование предложений и инициатив государству и открытие отделений ДЕС в каждом губернаторстве Египта.

В 2012-2015 гг. ДЕС организовал серию встреч под названиями «Знать», «Жить», «Сотрудничать», «Работать», в рамках которых мусульманское и христианское духовенство (около 70 человек) совместно посещали мечети и церкви, больницы и республиканские стройки. Из других достижений можно выделить проведение Дня матери, молодежных спортивных состязаний, попытки добиться выступлений в СМИ. В 2015 г. ДЕС успел подписать договор с Университетом 'Айн алШамс и провести на его базе культурный форум под названием «Синай - земля разных религий».

ДЕС очень активен: организует мероприятия и участвует в проектах своих партнеров. Но, к сожалению, как мы видим, он по большей части работает для государства, а не для самих граждан. Создав ДЕС, власть создала видимость работы над решением проблемы религиозного противостояния, при этом она совершенно игнорирует настоящие причины возникновения конфликта: пробелы в законодательстве, безработицу, коррупцию, что в основном и побуждает молодежь присоединяться к экстремистам. Иногда под длинными формулировками, трюизмами и бесконечными рефренами скрывается обычное бездействие. Однако, на наш взгляд, это лучше, чем ничего. 


\section{ПОЛИТИЧЕСКИЕ НАУКИ И РЕГИОНОВЕДЕНИЕ}

Представители ДЕС очень сдержанно комментируют новые межрелигиозные столкновения. К примеру, в заявлении ДЕС по поводу событий в деревне ал-Карам (Минья) в мае 2016 г. не было написано ни строчки об осуждении или одобрении чьего-либо поступка. Все ограничивается повторением клише: «мы стремимся уважать Конституцию и закон», «мы хотим сохранить национальное единство... равенство... мирное сосуществование, безопасность общества». Особо подчеркивается скорое вмешательство в кризисную ситуацию президента 'А.Ф. ал-Сиси (2014 - н. в.).

Рупором ДЕС является газета «Миср ва ал-хилва» Коптского культурного центра. В ней публикуются статьи о единстве нации, жизни христиан и мусульман, обсуждаются внешнеполитические события.

К примеру, в этом издании несколько лет назад была напечатана статья Гиргиса 'Ибрахима Салеха «Мусульмано-христианское сосуществование. Реальность и надежды» ${ }^{4}$. По мнению автора, в большинстве арабских стран между мусульманами и христианами установились дружественные отношения ${ }^{5}$. Христиане могут свободно отправлять религиозный культ, использовать СМИ для вещания своих программ ${ }^{6}$. Между лидерами общин поддерживаются хорошие отношения: «У нас одно гражданство, одинаковые права, и шейх Ахмад ал-Тайаб поддерживает этот баланс».

Между тем проблема межрелигиозной вражды в Египте более серьезная. До сих пор ведутся дискуссии, являются ли копты полноценными гражданами или все-таки они ограничены в своих правах, как это понимал Сайид Кутб (1906-1966) 7.

Межрелигиозное напряжение в стране существует постоянно, оно ослабевает только в моменты обострений общенациональных проблем, таких как война или смена коррумпированного режима. В 2011 г. это проявилось в коллективном пении молитвы «Отче наш», где принимали участие мусульмане. Копты на площади Тахрир охраняли мусульман во время совершения намаза. Атмосферу единения прекрасно передавал лозунг «Мусульманин или христианин - мы египтяне!».

После ухода Хосни Мубарака в обществе развернулись дебаты по поводу второй ста- тьи Конституции страны, закреплявшей принципы исламского шари'ата в качестве главного источника законодательства. Салафитская партия «Нур» хотела расширить статью и объявить источником не только принципы, но и весь исламский закон. Их оппоненты, немусульмане и либералы, считали, что такая статья не может существовать в правовом государстве в принципе. В Конституции 2012 г. инициатива салафитов не воплотилась, но в ней также не был упомянут принцип «ал-муватана» («наша Родина») ${ }^{8}$, который присутствовал в первой статье Конституции 2007 года.

Невозможно сказать, что риторика исламистов исключительно антихристианская. АБМ как пример умеренного исламизма демонстрирует разные подходы к религиозной политике в стране. Внутри АБМ делится на фракции, каждая из которых придерживается собственного мнения в вопросе прав коптов. Представители старшего поколения, то есть консерваторы, сформировавшиеся в 40-50-е гг. XX в., настаивают на подражании Средневековью. Реформисты, напротив, готовы адаптировать шари'ат к современным условиям.

В апреле 1995 г. под влиянием реформаторов АБМ выпустила «Обращение к народу», в котором подтверждалось равенство в правах коптов и мусульман. Старшее поколение ассоциации было обескуражено заявлением, поэтому будущий верховный наставник Мустафа Машхур (1996-2002) был вынужден выступить с других позиций: «Копты не должны быть допущены к высшим должностям в армии, потому что подчинение христиан обеспечивает их лояльность египетскому правительству в условиях конфронтации с христианскими государствами. К тому же копты должны платить джизью (подушную подать. - O. H.), как это сложилось исторически» [8, p. 70].

Известный политик 'Абу ал-'Ула Мади в желании сблизить ислам и западные ценности вошел в конфронтацию с руководством АБМ и покинул движение. До этого у него получилось организовать партию с говорящим названием «Ал-Васат» («Середина»), а после стать одним из активных участников движения «Кифайа» («Хватит!»), в равной степени критикующего правящую партию и АБМ.

Исламисты все же не оставляли попыток привлечь коптское население на свою сто- 
рону. В январе 2006 г. лидеры АБМ обещали выпустить «Белую книгу» по правам коптов как граждан, но слово не сдержали. На выбо$\operatorname{pax} 2011$ г. от исламистов баллотировалось 93 христианина, а копт-протестант Рафик Хабиб был выбран вице-председателем партии «Свобода и справедливость» (политическое крыло АБМ).

До и после своего избрания президент Мухаммад Мурси (2012-2013) осуждал теракты против коптов. В частности, он объявил, что атака на собор Святого Марка в деревне ал-Хусус 7 апреля 2013 г. - это атака лично на него.

Другой острый вопрос состоит в том, являются ли копты меньшинством в Египте. Мусульмане, придерживающиеся государственного идейного курса, а также руководство КПЦ отрицают этот факт и заявляют, что копты - это не меньшинство, а часть египетского народа (часть большинства). В этом суждении кроется логическое противоречие.

В 1994 г. в Каире прошел конгресс по правам меньшинств в арабском мире и Ближнем Востоке, который выделил коптов как одну из этнорелигиозных групп наравне с курдами Ирака и армянами Ливана. Известный египетский журналист Мухаммад Хасанайн Хайкал (1923-2016) и патриарх Шенуда III раскритиковали участников конференции [5, p. 22].

В 1985 г. некоммерческими организациями была основана Египетская ассоциация прав человека, в сферу интересов которой входила защита христиан от террора. Позже на общественной арене появилась ассоциация «Религиозное братство», в которой люди объединялись на основе веры в Бога, несмотря на различие в догматике и религиозной практике. В этом движении были не только светские участники, но и представители АБМ, которые проводили совместные 'uфтары, где поднимались вопросы о будущем общества.

Епископ по делам молодежи 'Анба Муса (р. 1938) вдохновлял молодых коптов встречаться с мусульманами во время межрелигиозных дискуссий, которые начались в 1985 г. и стали более интенсивными с 1989 г.: «Это пробел, который мы должны преодолеть; нам не нужно сидеть сложа руки и ждать - напротив, действовать с христианской любовью.
Подтолкни молодых коптов быть среди своих мусульманских братьев, так они не будут изолированы, но найдут свое место в группах или в клубе. Если мы прекратим сотрудничество, то это нанесет ущерб обеим сторонам» [7, p. 51].

Епископство по делам молодежи придумало модель, по которой мусульмане разделяются на 5 категорий:

1) представители государственного ислама;

2) либеральные мусульмане;

3) умеренные мусульмане;

4) экстремисты;

5) террористы.

С каждой группой епископство предлагает выстаивать особую линию поведения. Отношения с государственным исламом выстраиваются через официальные встречи с участием патриарха. Со второй и третьей группами рекомендуется постоянно поддерживать контакты. Бесполезно тратить силы на общение с экстремистами и террористами, так как их идеология отрицает диалог с немусульманами. Четвертая группа, правда, продолжает находиться под особым вниманием Церкви, потому что она неоднородна и внутри нее могут быть люди, которые захотят войти в диалог с христианами.

В первой половине XX в. основатель АБМ Хасан ал-Бана (1906-1949) в трактате «Обучающие послания» (Рисалат ал-та'лим) также попытался провести социальную стратификацию египетского общества. Проанализировав его, он разделил людей по категориям:

1) верующие мусульмане, ведущие джихад;

2) пассивные мусульмане;

3) грешные мусульмане;

4) зимми.

Комментаторы Хасана ал-Баны 'Абд 'Аллах ал-Катиб и 'Абд ал-Халим Хамид в 1990 г. разъяснили, как нужно вести себя с каждой группой. В частности, по их мнению, с зимми нужно проявлять терпимость и быть справедливым.

В 1990-е гг. епископ Бану Суэф Афанасий (1923-2000) реанимировал идею создания школ, в которых дети мусульман и христиан могли бы учиться вместе и завязывать дружеские отношения. Школы существовали на взносы и пожертвования, дети из бед- 
ных семей могли поступить, заплатив минимальную плату.

Большинство западных ученых сходятся во мнении, что на современном этапе в Египте установилась неомиллетная система отношений между религиозными общинами ${ }^{9}$. Коптский патриарх является официальным представителем всей общины перед лицом государства. Споры о том, насколько патриарх действительно выражает мнение своей паствы, а не занимается идеологическими обоснованиями решений государства, продолжаются с 1985 года. Шенуда III во всем поддерживал Хосни Мубарака, взамен требуя от него защиты своего народа ${ }^{10}$. В первые дни революции 2011 г. он выступил с обращением к коптам, призывая их не поддаваться на провокации и не выступать против президента ${ }^{11}$. Однако, как только стало понятно, что Хосни Мубарак не сможет договориться с протестующими, Церковь изменила свою позицию. Уже 15 февраля она издала коммюнике с поддержкой революции, в котором приветствовалась армия и Высший совет революционных сил.

Результаты. По нашему мнению, современные межрелигиозные отношения в Египте можно охарактеризовать как застойные. Между КПЦ и институтами официального ислама поддерживаются контакты на уровне протокольных визитов, заявлений против экстремизма и терроризма, объявления о своей приверженности государственному курсу. Военные, вставшие у руля государства после июльского переворота 2013 г., не привнесли никаких изменений в религиозную политику. Президент 'А.Ф. ал-Сиси придерживается тех же принципов, что и его предшественник Хосни Мубарак. Он продолжает поздравлять коптов с Рождеством и Пасхой и обещает сделать все возможное для обеспечения мира и согласия в Египте. Высшему исламскому духовенству также гарантируется неприкосновенность при условии поддержки президентского курса. Все без исключения руководители Египта с 1956 г. придерживались авторитарного стиля руководства страной, подавляя более или менее сильную оппозицию. В высшей степени признание за соперником его влияния на граждан проявляется, когда президент обвиняет его в создании «го- сударства в государстве». Таких слов удостаивался патриарх Шенуда III в 1980 г. и руководство АБМ в 1995 году.

Несмотря на демократические лозунги, Хосни Мубарак и 'А.Ф. ал-Сиси фактически воплотили в своем государстве образец электорального авторитаризма. В этих условиях религиозные институты рассматриваются государством, прежде всего, как средство утверждения своей власти в массах. Данная мысль совпадает с мнением Б.С. Тернера о том, что религия через религиозные институты трансформировалась в систему, главной задачей которой является не формирование мировоззрения, а поддержка секулярного мира [6, p. 31]. В Египте КПЦ и все исламские течения осуждают атеистическое общество Запада, противопоставляя ему свою духовность, которая не могла бы существовать без заботы о том властей.

Христиане и мусульмане вынуждены жить в этой парадигме. Так как большинство населения исповедует ислам, власть прежде всего играет на их религиозных чувствах. В связи с тем, что массовое строительство церквей может вызвать недовольство мусульман, власть не снимает ограничения на постройку храмов. Дела о межрелигиозных столкновениях часто не доходят до судов, а разрешаются в пользу мусульман через давление на коптов со стороны силовых структур.

Исламисты-реформаторы, в отличие от консерваторов, готовы пойти на уступки христианам и сделать их равноправными гражданами, несмотря на предписания шари“ата. Реформаторы в своих взглядах близки к либеральной интеллигенции, которая из-за недальновидности упустила победу на президентских выборах 2012 г. и возможность реализации своих идей на практике.

Египет, как и западные страны сто лет назад, переживает исторический кризис. В стране происходит смена эпох, которая выражается в смерти старой картины мира и рождении новой. Подобные события уже происходили со страной во второй половине XIX начале XX в. после открытия «новой Европы», когда рост научного знания бросил религии вызов. В этих условиях духовенство могло пойти двумя путями: либо переосмыслить свои религиозные убеждения, устраняя противоре- 
чие между ними и наукой, либо замкнуться в себе и подвергнуться саморазрушению. Благодаря идеям просветителя Джамал ал-Дина ал-'Афгани (1838-1897) египетское общество выбрало первый путь.

В XXI в. Египет снова столкнулся с той же дилеммой. У страны есть шанс продолжить развитие, отделив религию от государства и предоставив своим гражданам равные права не только на словах, но и на деле. Вопрос, сможет ли египетское общество справиться с этими трудностями, остается открытым.

\section{ПРИМЕЧАНИЯ}

${ }^{1}$ В исламе отсутствует институт Церкви, поэтому на многие богословские и практические вопросы мусульманские ученые имеют диаметрально противоположные мнения. Отношения с немусульманами считаются ахиллесовой пятой фикха: единой канонической интерпретации 'айатов Корана и хадисов, которые затрагивают эту тему, не существует.

${ }^{2}$ Находился в должности с 3 марта по 21 ноября 2011 года.

${ }^{3}$ По его собственному признанию, эта мысль пришла ему «на ум» после нападения 31 октября 2010 г. на церковь Богородицы в Ираке «Сайида алНаджат» (Госпожа Спасения) и угроз со стороны «ал-Ка“'иды» в отношении египетских церквей.

${ }^{4}$ Управляющий экуменическими связями и диалогом в КПЦ, профессор, преподаватель Ветхого Завета в Теологической семинарии Института коптских исследований, почетный секретарь Совета ближневосточных церквей (Middle East Council of Churches, MECC).

${ }^{5}$ Для сравнения: религиозная организация христиан-евангелистов США «Open Doors» заявила, что 9 из 10 самых неблагоприятных стран для христиан - арабские. На 10-м месте стоит Северная Корея [4, р. 62-63].

${ }^{6}$ Для сравнения: время коптских религиозных передач на телевидении ограничено несколькими часами, в то время как мусульманские программы вещают круглосуточно [2]. А также: в Египте запрещены дебаты между христианами и мусульманами. Государственное телевидение освещает события религиозной жизни коптов 5 часов в год и 3000 отводит для ислама [7].

${ }^{7}$ Египетский писатель и философ, один из идеологов движения «Братья-мусульмане».

${ }^{8}$ Египетские мыслители начали развивать концепцию «ал-муватана» с конца 1980-х гг. на основе идей современных западных социологов Ю.Э. Ха- бермаса, Б.С. Тернера, Т.X. Маршалла. Активисты создали целую организацию под названием «Миср ал-муватана» для популяризации этой идеи. Другим похожим объединением стали «Египтяне против религиозной дискриминации». К концу правления Хосни Мубарака эта идеология вышла на первый план, возможно, чтобы представить его как демократа. Термин активно использовался правящей Национально-демократической партией Египта в 2006-2011 годах. Концепция противопоставляла государственную толерантность религиозному государству. Лозунг «Ислам - вот решение!» был переформулирован в «Гражданство вот решение!».

${ }^{9}$ Миллетная система начала складываться в Османской империи после падения Константинополя в 1453 г., когда султан назначил Константинопольского патриарха и дал ему абсолютную власть над христианами в духовной и гражданской жизни.

${ }^{10}$ Официальное издание Коптской церкви «АлКираза» во время президентской гонки 2005 г. опубликовало ряд статьей в поддержку Хосни Мубарака. 'Анба Бешой, секретарь Священного синода при Шенуде III, описал Гамаля Мубарака как лучшего приемника своего отца на посту президента: «Мубарак всегда стоял за нас и давал нам наши права, и его сын - порядочный человек, который любит коптов» [3, p.172].

${ }^{11} \mathrm{~B}$ свою очередь 'имамы подконтрольных Министерству вакфов мечетях в пятничных проповедях призывали прихожан не ходить на «греховные» протесты.

\section{СПИСОК ЛИТЕРАТУРЫ}

1. Fahmi, G. Dialogue as Tool for Addressing Religious Tension: Containing the Violence, or True Conflict Resolution / G. Fahmi // Dialogue and Conflict Resolution. Potential and Limits. - UK: Ashgate, 2015. - P. 189-209.

2. Ibrahim, V. Beyond the Cross and the Crescent: plural identities and the Copts in contemporary Egypt / V. Ibrahim. - Electronic text data. - Mode of access: https://olemiss.academia.edu/VivianIbrahim (date of access: 12.12.2017). - Title from screen.

3. Monier, E. I. The Arab Spring and CopticMuslim Relations: From Mubarak to the Muslim Brotherhood / E. I. Monier // European Yearbook of Minority Issues. - 2012. - Vol. 11. - P. 168-185.

4. Seckler, A. C. Religion is not the Answer. How to Turn Restlessness into the Meaningful Change / A. C. Seckler // CUNY Academic Works. - Electronic text data. - Mode of access: https://academicworks. cuny.edu/cgi/viewcontent.cgi?article $=1506 \&$ context $=$ gc_etds (date of access: 12.12.2017). - Title from screen. 


\section{ПОЛИТИЧЕСКИЕ НАУКИ И РЕГИОНОВЕДЕНИЕ}

5. Sevenaer, Ch. van N. tot . Changes in Relations between Copts and Muslims (1952-1994) in the light of the Historical Experience / Ch. van N. tot. Sevenaer // Between Desert and City: The Coptic Orthodox Church Today. - Eugene : Wipf and Stock Publ., 1997. P. 22-36.

6. Turner, B. S. Religion and Modern Society. Citizenship, Secularism and the state / B. S. Turner. N. Y. : Cambridge University Press, 2011. - 344 p.

7. Van Doorn-Harder, P. Fully Egyptians, but for a Tatoo? / P. Van Doorn-Harder // Nationalism and minority identities in Islamic societies. - Montreal : McGill-Queen's Press, 2005. - P. 22-57.

8. Wickham, C. R. The Muslim Brotherhood. Evolution of an Islamist Movement / C. R. Wickham. Princeton, N. J : Princeton University Publ., 2013. -360 p.

\section{REFERENCES}

1. Fahmi G. Dialogue as Tool for Addressing Religious Tension: Containing the Violence, or True Conflict Resolution. Dialogue and Conflict Resolution. Potential and Limits, 2015, pp. 189-209.

2. Ibrahim V. Beyond the Cross and the Crescent: plural identities and the Copts in contemporary
Egypt. URL: https://olemiss.academia.edu/ VivianIbrahim (accessed 12 December 2017).

3. Monier E.I. The Arab Spring and CopticMuslim Relations: From Mubarak to the Muslim Brotherhood. European Yearbook of Minority Issues, 2012, vol. 11, pp. 168-185.

4. Seckler A.C. Religion is not the Answer. How to Turn Restlessness into the Meaningful Change. CUNY Academic Works. URL: https:// academicworks.cuny.edu/ cgi/viewcontent.cgi? article $=1506 \&$ context $=$ gc_etds (accessed 12 December 2017).

5. Sevenaer Ch. van N. tot. Changes in Relations between Copts and Muslims (1952-1994) in the light of the Historical Experience. Between Desert and City: The Coptic Orthodox Church Today. Eugene, Wipf and Stock Publ., 1997, pp. 22-36.

6. Turner B.S. Religion and Modern Society. Citizenship, Secularism and the State. New York, Cambridge University Press, 2011.344 p.

7. Van Doorn-Harder P. Fully Egyptians, but for a Tatoo? Nationalism and minority identities in Islamic societies. Montreal, McGill-Queen's Press, 2005, pp. 22-57.

8. Wickham C.R. The Muslim Brotherhood. Evolution of an Islamist Movement. Princeton, N. J; Princeton University Publ., 2013. 360 p.

\section{Information about the Author}

Oksana V. Nizamutdinova, Postgraduate Student, Department of Altai Studies and China Studies, Kazan Federal University, Pushkina St., 1/55, 420111 Kazan, Russian Federation, ok.nizam@yandex.ru, https://orcid.org/0000-0002-1238-8888

\section{Информация об авторе}

Оксана Викторовна Низамутдинова, аспирант кафедры алтаистики и китаеведения, Казанский федеральный университет, ул. Пушкина, 1/55, 420111 г. Казань, Российская Федерация, ok.nizam@yandex.ru,https://orcid.org/0000-0002-1238-8888 